\title{
Novelistas españoles y memoria histórica en el siglo XXI
}

La memoria histórica forma parte del patrimonio de la humanidad desde finales del siglo XX. En España permanecen aún los nefastos recuerdos de la Guerra Civil de 1936-1939 y sus secuelas. Frente a este conflicto domina, al principio del siglo XXI, la oposición entre dos ideologías: la "desmemoria" y la urgencia de elucidar el pasado para lograr encontrar la verdad. Los novelistas españoles han abundado en escribir sobre la guerra fratricida y el Franquismo desde su mismo principio, pero de manera insistente desde principios del presente siglo. La Ley de la Memoria Histórica, promulgada en el 2007, permitía revisar todos aquellos años difíciles de la historia del país y ha sido un excelente incentivo para los narradores. Un centenar de autores, muchos de ellos entre los de mayor renombre en la novelística actual, adoptaron una estrategia narrativa poco usada antes: la metaficción en todas sus variantes, desde la más sencilla, como la del texto o libro encontrado, hasta la más compleja, jugando entre la realidad y la ficción, y arrastrando al lector a un laberinto a veces casi inextricable. Basándome en los críticos más conocidos sobre el género analizo las novelas de más relieve escritas en España desde el año 2000.

La memoria histórica va formando parte del patrimonio de la humanidad desde finales del siglo XX. Los diferentes países que sufren guerras o revoluciones prolongadas están obsesionados por ellas durante décadas y tratan, poco a poco, de superar el dolor, a menudo con obras de arte en el cine, la música y las canciones, en la pintura y en la literatura. España es uno de los países donde más se perciben aún, décadas después, los efectos de la última Guerra Civil: ochenta años han pasado y los que la vivieron y hasta sus biznietos no la olvidan. Las tres últimas décadas de su historia se inscriben en las constantes del posmodernismo, de la "déshistoricisation" (Cros 17) a la vez que de "una eclosión de movimientos locales de naturaleza nacionalista" (Navajas, "Novela" 13). Domina la oposición entre dos ideologías: por una parte, el deseo de hacer tabla rasa del pasado, de la tragedia de los años treinta, calificado de "desmemoria" por muchos, y por otra parte, la urgencia no menos angustiosa de volver a ese pasado para elucidarlo, entenderlo mejor para comprenderse a sí mismo.

Los novelistas españoles, por su parte, han abundado en escribir sobre la Guerra Civil y el Franquismo desde su mismo principio, pero lo han 
hecho de manera especial e insistente desde principios del presente siglo. La Ley de la Memoria Histórica promulgada en el 2007 permitía revisar, tanto de la Guerra Civil como del Franquismo, los juicios sumarios, abrir las fosas comunes, retirar los símbolos franquistas, incluir a "todas" las personas fallecidas entonces en el Valle de los Caídos, conceder la nacionalidad española a los que pertenecieron a las Brigadas Internacionales y crear un Centro Documental de la Memoria Histórica en

Salamanca. ${ }^{2}$ Esta ley ha colaborado en gran parte a incitar a los autores a escribir sobre este tema tan difícil emocionalmente. Muchos de ellos adoptaron una estrategia narrativa poco usada antes: la metaficción en todas sus variantes.

Varias novelas publicadas desde el año 2000 llevan la palabra "memoria" en su título y las iré analizando a lo largo de las páginas siguientes pero quiero señalar primero un texto narrativo particular: $i O t r a$ maldita novela sobre la guerra civil! Lectura crítica de la malamemoria (2007) de Isaac Rosa. ${ }^{3}$ Su título, además de llamativo, abarca los tres ejes principales de mi trabajo: la memoria, la Guerra Civil Española y la metaficción. El narrador, un profesor de Instituto, "negro" de varias personalidades, ha escrito una novela sobre la guerra, "La malamemoria", no ha logrado publicarla y la rehace comentándola. Le llama una viuda y le pide que escriba las falsas memorias de su difunto marido, un hombre atrapado "por el torbellino de sangre de aquel tiempo" (38). Va investigando y, poco a poco, se da cuenta de que "más que un viaje al pasado de su personaje es una excursión a tu propio pasado" (50), y se vuelve a ver a sí mismo cuando era pequeño y su madre le mandaba de noche a llevar comida a su padre escondido en la sierra. Después de varias peripecias, el narrador vuelve a Madrid, va a visitar a la viuda y, al no encontrarla, se va a la casa de la sierra de esta para decirle que no quiere continuar el trabajo. Aparece entonces el marido que ha fingido el suicidio, se enfrentan ambos y el narrador acaba por marcharse "para encontrar un nuevo territorio, un horizonte menos vago ... para vivir" (443).

El autor-narrador mismo critica en bastardilla a la vez que la suya las novelas recientes sobre la guerra - "Nuestro joven autor parece decidido a aprovechar un recurso narrativo..." (208). Saca a relucir todos sus defectos, sus torpezas y sus características, explicando cómo deben ser los libros (62), los personajes (63); juega constantemente con las tres personas del verbo, utiliza varios narradores, el diario del supuesto difunto y los comentarios de varios informantes. La importancia de la Guerra Civil es recordada por medio de una cita de Montaigne empleada como epígrafe "Nada graba tan fijamente en nuestra memoria alguna cosa como el deseo de olvidarla" (13) - que tan bien se aplica a nuestro tema. Se pregunta el 
autor-comentarista al final, “¿[q]ué queda de esa mala memoria...” y concluye:

Novelas como ésta pueden hacer más daño que bien en la construcción del discurso sobre el pasado ... Debido a las peculiaridades del caso español, a la defectuosa relación que tenemos con nuestro pasado reciente, la ficción viene ocupando ... un lugar central que tal vez no debería corresponderle. (444-445)

En Isaac Rosa se reconoce el tono de muchas novelas que refieren el conflicto que siguió el alzamiento de los generales en 1936: el horror de lo que fue el pasado, el resentimiento que no acaba de extinguirse, la necesidad de olvidar de una vez, de reconciliación.

Sin embargo, no todos los autores que escriben desde el 2000 están de acuerdo con el no recordar, como lo prueban varias obras, entre otras la de José Manuel Ruiz Marcos, La memoria y el silencio (2008), una novela histórica sobre la Guerra Civil en Asturias. Como muchos, el narrador quiere volver a sus orígenes, al lugar de sus estupores, a Ustium en Asturias, contar "Todo lo que los años treinta dejaron larvado en mí, jeroglíficos que aquel niño era incapaz de descifrar" (7); quiere contar lo que de veras pasó (9). Pero se pregunta: “¿[y] ello en una novela? Sí. El novelista documentado llega adonde no alcanza la historia, tiene el privilegio de rellenar huecos y lagunas" (9). Afirma muy seguro, después de haber señalado su afán de justicia, de verdad histórica: "El protagonista de estas páginas es el pueblo entero. Todos en él fueron autores, los dos bandos" (8).

Como Almudena Grandes en El corazón helado (2007), Ruiz Marcos expone los amores de dos personas que se encuentran y se dan cuenta de que sus historias son semejantes: sus padres han vivido la Guerra Civil de niños en bandos opuestos y les pesa tremendamente aquel pasado. Alterna la voz de cada uno de los protagonistas en primera persona y la de un narrador omnisciente en tercera persona, pero domina sin duda la perspectiva autobiográfica, la memoria personal. Sus padres vivieron en un magma de resentimientos y de venganzas sin distinción de bandos y no logran echar fuera sus fantasmas.

Metaficción, historia y autobiografia, extraña mezcla sin embargo eficaz, como la encontramos de nuevo en Perdidos en la memoria. Chiclana, Marzo de 1939: La tragedia del Castillo de Olite (2010) de Luis Mollà Ayuso. Aquí el autor propone a dos jóvenes de diferentes ámbitos sociales que hacen una investigación sobre un barco mercante hundido frente a Cartagena con sus 2000 soldados a bordo durante la guerra. Se enfrentan con muchas contradicciones, se van enamorando y se preguntan cuál fue 
el papel de Franco en la expedición y por qué cayó en el olvido tal masacre.

El autor, capitán de navío de la Armada, conoce bien los hechos relatados y sin duda el texto es en parte autobiográfico. Todo el libro refleja perfectamente las circunstancias sociales y políticas del momento de enunciación, como lo demuestra este diálogo: "Aprovecha la movida de la memoria histórica ... Eso es una milonga que se ha inventado Zapatero para que nos acordemos de su abuelo; lo cierto es que en ambos bandos se ejecutó a mucha gente. Puede que unos cincuenta mil en cada bando pero es algo que teníamos superado desde la Transición" (36).

Bien escrito, con abundantísimos diálogos eficaces, la novela ofrece, como tantas desde el final del siglo XX, una acción en progreso a lo largo del relato. El narrador explica los pasos que dan sus personajes para llegar a sus fines, y su opinión política aflora en varias ocasiones; duda de las intenciones de Franco pero no puede condenarle; una cosa segura para él y uno de sus personajes es la fealdad, el horror de la guerra:

¿Han visto los documentales que ponen en la televisión? Son una patraña. La guerra no es así: es más sucia, más inhumana, más cruel, una verdadera calamidad, créanme. No es solo el esfuerzo físico, el dormir poco y mal, el que te coman las chinches o pasar hambre y frío; eso no es nada comparado con la tortura psicológica de ver caer a los compañeros sabiendo que el siguiente puedes ser tú; saber que detrás de cada muerto hay una historia, una madre, una novia, esposa o hijos de los que te han venido hablando... (124)

Los tres autores que acabamos de ver no figuran entre los de más renombre en el período que estudio aquí, si bien no dejan de tener su interés. ${ }^{4}$ Otros como Javier Cercas, Dulce Chacón, Manuel Chirbes, Almudena Grandes, Javier Marías, Luis Mateo Díez, Eduardo Mendoza, José María Merino, Antonio Muñoz Molina, Carme Riera, Manuel Rivas, Carlos Ruiz Zafón, Jorge Semprún, Andrés Sorel, y Andrés Trapiello, entre otros, son mucho más conocidos. Y como los tres que acabo de citar, varios de ellos han recurrido a la reflexión entre la realidad y la ficción. ${ }^{5}$

La metaficción es una técnica antigua y se puede encontrar, como he dicho más arriba acerca de la memoria histórica, una gran variedad de medios narrativos, en novelas, cuentos, pero también en dramas, melodramas o comedias, o películas, y asimismo en medios no narrativos como en las artes visuales. En la novela, en general, quizá sea el Quijote el ejemplo más destacado de juego entre narrador y lector. En él, Cervantes lanza una invectiva contra los libros de caballería, parodia dicho género pero confía a Cide Hamete Benengeli el relatar la historia de sus personajes. Declara en el Prólogo: “[A]unque parezco padre, soy padrastro 
de don Quijote" (10). Esta forma sencilla de metaficción, este delegar la autoría del texto en otro, sea personaje real o ficticio, se ha cultivado en múltiples ocasiones a lo largo de los siglos.

Volviendo al tema básico del presente trabajo, la lucha fratricida del 36, el primer autor que analizaré ahora es Andrés Trapiello. Apasionado por la historia española de los años treinta, propone una obra basada en el texto de otro en Días y noches (200o), el diario del joven soldado Justo García, encontrado en la Fundación Pablo Iglesias. Se trata pues de una mise en abyme como lo califica Lucien Dallenbach: el narrador relata las circunstancias de su descubrimiento y va más allá del texto mismo dando detalles sobre la vida del personaje después de la escritura de su diario, por medio de la voz de su hija encontrada en México.

Todo ello responde bien a técnicas a la vez modernas y antiguas, recordemos simplemente de nuevo a Cervantes, pero Trapiello va más allá en el uso de la técnica narrativa, prolonga la historia de su personaje. Justo García Valle, un joven tipógrafo madrileño, combate con los republicanos y decide escribir su diario. Lucha con lo que queda de su División cerca de Ripoll cuando empieza la derrota, y cuenta lo difícil y lo penoso de las batallas, sobre todo porque saben que van a perder, y comprende que "esto no tiene ningún sentido" (62). Forma un grupito con unos amigos y el capitán les obliga a buscar comida donde sea. Encuentra a un niño desvalido y en brazos lo lleva por los montes hasta entregarlo. Acaba por pasar a Francia, es internado en el campo de Saint-Cyprien, sufriendo todas las miserias de tan sórdido lugar. Vive en Toulouse, en París y logra encontrar un pasaje en el barco "Sinaia" que le lleva a Veracruz, México. Vuelve a encontrar a Clara, una joven conocida de la guerra y casada con un amigo común, se enamora de ella pero sabe que no tiene ninguna posibilidad de conseguir nada de ella. Su desesperanza es total al final del diario. Bien escrita, con su dosis de lirismo, sus buenas descripciones del final de la guerra, de la desolación de la pérdida de las ilusiones, de la huida a Francia, de la dureza de los franceses y del desencanto del hombre forzado a abandonar el suelo patrio, la obra fue traducida en seguida al francés con el título: Les cahiers de Justo García.

Bernardo Atxaga, en El hijo del acordeonista (2004), utiliza la misma técnica que Trapiello, pero la torna más compleja, rehace el relato de otro narrador, lo comenta, lo completa y lo publica. Otra vez tenemos un juego de cajas chinas o de matriochka. Premio Nacional de la Crítica, esta novela narra la historia de dos amigos del País Vasco, Joseba y David. Este se casó con una norteamericana, vivió en California con su familia y Joseba le fue a ver antes de su muerte; con Mary Ann, su viuda, decide retomar las memorias del difunto escritas en la "vieja lengua" (español) y hacer la 
historia de "dos hermanos". David tocaba el acordeón como su padre, que era partidario de los fascistas, contrariamente a su tío Juan, antifascista acérrimo. Al tener problemas con la policía, David marchó a San Sebastián para sus estudios universitarios en economía, empezó luego a trabajar para la liberación de su patria chica, estuvo en la cárcel, y continuó su misión en Francia. Sin embargo se desilusionó de la política pues no quería que siguiera la "bola de odio" y marchó a California.

El relato de Joseba engloba y reformula el que David había empezado y otros dos metarrelatos aparecen en el texto. ${ }^{6}$ David cuenta con lujo de detalles la vida en su pueblo vasco saltando en el tiempo y en el espacio y escogiendo ciertos acontecimientos destacados. Supo que había habido fusilamientos en su pueblo durante la Guerra Civil y aquello le torturó durante años: había pasado un cuarto de siglo cuando se enteró y, sin embargo, se puso furioso contra su padre, al cual sospechaba de ser el responsable de esos crímenes y de haberse rodeado de asesinos situación muy parecida a la de La sima de Merino que veremos más adelante -, y también se enfrentó a su madre, que no hizo nada para denunciarle. Opuesto a toda violencia, se acercó cada vez más a su tío Juan, de ideología antifascista: “¿Es que vamos andar siempre así, matándonos unos a otros?" (222); "Era descorazonador: la rueda del tiempo me traía realidades cada vez más tristes. Listas de fusilados y de chivatos, en lugar de listas de personas queridas" (238). Dejó el País Vasco para encontrar la paz, la serenidad y solo el amor logró rescatarle después del infierno de su adolescencia. $^{7}$

La novela de Nativel Preciado, Camino de hierro (2007), reúne también muchas de las características de la novela reciente. Presenta una trama doble, una encajada en otra, pero muy diferente de las obras ya presentadas: el amor infinito y sublimado de Paula y Lucas, por una parte, y por otra, la búsqueda del pasado del abuelo de Paula. Premio Primavera de Novela 2007, este texto escrito como una autobiografía de una nieta de un fusilado de la Guerra Civil es conmovedora. Paula ha sido abandonada por su marido y recibe por fin una carta de él, en la cual este le confía que se marchó porque sentía que arruinaba la vida de ella, e insiste en que vaya a cumplir su deseo de encontrar la memoria de su abuelo en León. Este trabajaba en los Caminos de Hierro del Norte de España, fue denunciado durante las hostilidades y sentenciado a muerte. Mucho más tarde, un hombre de la Comisión para la Recuperación de la Memoria Histórica ayuda a Paula en sus pesquisas. Aparece unos meses después el padre Joaquín para informarle que su marido está muriéndose en su convento. Paula, atrozmente dolorida, comprende la razón profunda de la carta que recibió, acude al lecho de muerte de su amado y, siguiendo lo mejor que 
puede los consejos del padre Joaquín, le ayuda a pasar al otro mundo tranquilo, sin dramas.

Estamos de nuevo ante un pacto de lectura diferente de la novela tradicional: subraya la narradora en más de una ocasión que va a "[e]scribir un libro sobre los desaparecidos ... otro libro más" (8o), y se pregunta "¿Cuántos centenares de libros se han escrito sobre este tema [de la Guerra Civil]?" (6o); señala que no está "preparada para recrear la memoria de una manera aséptica" (114), si bien quiere respetar la herencia de su abuelo, quien repetía: "El rencor y la venganza ... sólo sirven para prolongar la injusticia" (137). Varios narradores aparecen al lado de Paula, ${ }^{8}$ se reproducen las copias de las cartas escritas por el abuelo en 1941 (11625), el tiempo oscila entre el presente de la trama con referencias directas a hechos contemporáneos - "También tú vienes a desenterrar cadáveres" (72) - y también al pasado durante la contienda de 1936. La autora confiesa en el Preludio: "He contado este ensueño para dialogar con mis muertos, firmar la paz con mis antepasados y, sobre todo, conmigo mismo" (12), y la narradora recalca su odio a la lucha fratricida: "Nada hay más execrable que una Guerra Civil como la nuestra. Ya sé que no la vivimos, pero la llevo grabada en mi cerebro" (195). Nos acercamos en este texto, además de los de Trapiello y de Atxaga ya analizados, al de Javier Cercas y de otros que veremos más adelante; la autora va explicando cómo procede para escribir su libro, participamos en su proceso de escritura.

Hoy en día se asocia este tipo de escritura, la metaficticia, a la literatura postmoderna, la que permite a los autores el hablar de sentimientos y pesares tremendos de forma indirecta, utilizando otros textos u otros personajes, y de manera lúdica, llamando la atención sobre la naturaleza ficticia de su texto, sobre su condición de artefacto. Múltiples definiciones se han dado de la metaficción y el término, como el de metapoesía o de metateatro, es relativamente reciente y proviene de la lingüística -el metalenguaje de Roman Jakobson en 1958- y en 1959 Roland Barthes empleaba la palabra metaliteratura. ${ }^{9}$ Tanto el francés Lucien Dallenbach como los norteamericanos Robert Alter y Robert Spires y los españoles Ana María Dotras y Gonzalo Navajas (Más allá; Narrativa; Teoría) han tratado de circunscribirla y de enmarcar las diferentes formas que toma. ${ }^{10}$

En la década de los ochenta ya se había discutido bastante sobre esta "nueva" forma de escribir novelas, y Linda Hutcheon y Patricia Waugh se destacaron con dos estudios muy serios y aportando análisis muy detenidos. Para Hutcheon la metaficción es eminentemente narcisista, es "fiction about fiction", ficción en torno a la ficción, o lo que es lo mismo, ficción que incluye en sí misma un comentario sobre su propia identidad 
narrativa y la lingüística. Dos modos principales se encuentran en este género, el diegético, es decir, el enfocado en la conciencia del proceso de narrar, y el lingüístico, más centrado en el lenguaje, en su poder y también en sus límites. Otro punto capital señalado por Hutcheon es la necesidad absoluta de la participación del lector que tiene que hacerse co-creador: "Se le deja que cree su propio significado, que rellene el hueco, que active la obra. Está avasallado, frustrado en sus expectativas normales de lectura" (150; mi traducción).

Patricia Waugh, por su parte, insiste más en el aspecto social: "Metaficción es el término atribuido a aquellas obras de ficción que, de una forma autoconsciente y sistemática, llaman la atención sobre su propia condición de artificio creado para así suscitar preguntas en torno a las relaciones entre ficción y realidad" (2; mi traducción). Rechaza la tendencia moderna de la crítica a condenar la novela a la muerte $y$, al contrario, constata su vigor al considerar la novela metaficticia como prueba de la superación del realismo. Analiza varios aspectos de la metaficción en su obra: la autoconsciencia, la parodia, el carácter lúdico, imaginativo de esta tendencia, la metalingüística, el role-playing y la distinción entre metaficción moderna, asociada a la idea de conciencia, y la posmoderna, a la de ficcionalidad.

La acepción que atribuye Gonzalo Sobejano a la metanovela en el 2003 tiene el interés de englobarlas a casi todas:

Una novela que refiere a un mundo representado (fingido o imaginado en palabras) es una novela. Una novela que no refiere sólo a un mundo representado, sino, en gran proporción o principalmente, a sí misma, ostentando su condición de artificio, es una metanovela, de manera semejante a como el lenguaje que no remite a un mundo de objetos o contexto, sino a otro lenguaje o código, se llama "metalenguaje". (171)

A este tipo de literatura se apuntó José María Merino en dos obras recientes. En El heredero (2003) se acerca al conflicto de los años treinta con un protagonista que es nieto del conflicto trágico que se remonta hasta su tatarabuelo y, sobre todo, a su abuela en busca de sus raíces. Varios testimonios así como lo que encuentra en el antiguo caserón familar fascinan al nieto y relata los hechos en primera persona, pero en los momentos de gran angustia emplea la segunda. Halla cierto consuelo en el hecho de contar los horrores vividos pero sobre todo al recordar el cariño que sentía por su "Buli" y ella hacia él. Se interroga sobre la realidad y la ficción y concluye tristemente: "A mí me inocularon el remordimiento cainita" (427) y "las cicatrices familiares del enfrentamiento de la Guerra 
Civil ... acaso hayan dejado también en mí algunos residuos insospechados" (452).

Una segunda obra de Merino, La sima (2009), es la que mejor reúne las varias características de esta primera década del siglo XXI. Estamos en el 2005, a finales de año, y un profesor y doctorando de treinta y cuatro años prepara una tesis sobre la Primera Guerra Carlista, está muy preocupado por las numerosas "confrontaciones españolas" (25), y quiere "ordenar ciertas confusiones" (207) íntimas. Llega al pueblo de su niñez en la montaña leonesa, donde existe una sima: allí echaron cadáveres durante la Guerra Civil y se sospecha que su abuelo falangista fue el culpable. El día 5 de enero se deben hacer excavaciones para sacar los cadáveres de entonces.

Fidel escribe mañana, tarde y noche lo que le ocurre y lo que recuerda: el antagonismo de los ideales políticos de la familia paterna y de la materna, su orfandad prematura, su amor por su prima Puri, sus estudios para ser profesor, su nuevo encuentro con Puri y el embarazo de esta, los balazos del primo José Antonio. Ahora enseña en la universidad, pero ha caído en una profunda depresión: "Era la sensación de haber sido arrojado a una sima, de estar en el fondo de un pozo profundísimo" (310). Van llegando los espeleólogos y el primo José Antonio: durante la noche se oye una enorme explosión y la boca de la sima desaparece. Al borrarse la meta de su viaje, Fidel decide volver a Madrid pero Puri reaparece, ya separada del marido. Suben al monte, los alcanza José Antonio para matar a Fidel, pero Puri lo mata y tiran el cuerpo por un precipicio. El día 6, Fidel confiesa que la escena de la víspera la ha inventado él porque ya se ha dedicado a la novela; en la realidad Puri y él estuvieron juntos y Fidel pasó "la mejor noche de Reyes" de su vida; terminará su tesis o escribirá una novela, "Una novela de tesis, naturalmente" (414).

"L'autoreprésentation dans le récit de la fiction" (2001), artículo de Geneviève Champeau, ofrece una excelente síntesis de este fenómeno cada vez más frecuente, del relato en el cual el personaje se entromete en el texto como acabamos de ver en Merino. Champeau concluye de una manera convincente y clara su definición de la narración metafictiva: los relatos en los cuales se utiliza la reflexividad "miran hacia su 'ser' y sobre su 'hacer', llevando la atención del lector del universo diegético hacia la naturaleza y los principios de funcionamiento del objeto literario y de la comunicación que instaura" (65; mi traducción).

Este "ser" y "hacer" lo vemos de manera patente en Soldados de Salamina (2001) de Javier Cercas. Muy pronto cobró esta novela una fama increíble, hasta hablar pronto de un "antes" y un "después" de ella. Pero hay que señalar que, un año antes de Cercas, Juan Manuel de Prada había 
propuesto en Las esquinas del aire. En busca de Ana María Martínez Sagi (200o) una manera semejante de proceder, una forma diferente de escribir una novela, investigando a un personaje y describiendo los pasos del mismo autor como lo hace Cercas, el primero a Ana María Martínez Sagí y el segundo a Rafael Sánchez Mazas.

Según de Prada, la voz de Martínez Sagí se había perdido en "las esquinas del aire y del olvido, era un 'fantasma inconcreto'" (15) y el narrador trata de darla a conocer y al mismo tiempo darse a conocer él mismo. Martínez Sagi fue muy activa durante la Segunda República, en la guerra, en Francia y en el exilio. Volvió a España en 1975, pero no es sino hasta 1998 cuando el narrador la acaba por encontrar gracias a la intervención del poeta Pere Gimferrer. Persona real en el pasado, Martínez Sagí pasa a ser personaje en la novela, y de Prada se hace también personaje y va contando todas las etapas de su investigación para hacer literatura. ${ }^{12}$ Comparado con Javier Cercas, y a pesar de utilizar una técnica muy parecida a la suya, Prada tuvo poco eco en las letras en su momento, y sin duda, Cercas desconocía la obra que había precedido a la suya.

El narrador principal de Cercas, un periodista de Gerona, profesor de universidad, se entera del fusilamiento del escritor Rafael Sánchez Mazas en Collell al final de la Guerra Civil y de cómo milagrosamente las balas no hicieron más que rozarle. Busca información, se entrevista primero con el hijo de este, Rafael Sánchez Ferlosio, y escribe un artículo hablando tanto de la muerte de Machado del otro lado de la frontera como de la de Sánchez Mazas en la retaguardia catalana. Continúa su pesquisa acerca de varios informantes de todo calibre: el historiador Miquel Aguirre, el crítico y escritor Andrés Trapiello, el contratista Jaume Figueras, María Ferré, Joaquim Figueras y Daniel Angelats. Con la documentación acumulada, el periodista emprende la escritura de la biografía de su héroe.

Empieza con los datos conocidos y, al llegar al fusilamiento, se detiene y describe ampliamente la huida de Sánchez Mazas de tres días por la región de Banyols, su llegada a una masía, donde aparecen tres fugitivos republicanos, los hermanos Pere y Joaquim Figueras y Daniel Angelats. Completa el conjunto con informes más oficiales. Después de terminar el relato, se encuentra en Blanes con el escritor chileno Roberto Bolaño, y este le habla de un tal Miralles que fue soldado de la República, que tiene ahora ochenta y dos años y vive en Dijon, en Francia, en una residencia de ancianos. El narrador lo visita, y Miralles le cuenta su guerra recordando a sus compañeros jóvenes que murieron todos, y su nostalgia frente a un pasado tan triste y desolador. Charla largamente con él pero no le dice si fue él o no el que salvó la vida a Sánchez Mazas.

El narrador es a la vez el autor - "Mire, Cercas ... - Llámeme Javier" 
(176) - de esta metanovela - "pensar en mi libro, en Soldados de Salamina" (197) -, y parte de un encuentro, de hechos reales, y utiliza unas estrategias del mismo tipo que las de Andrés Trapiello en Días y noches y de las de Juan Manuel de Prada, pero Cercas elabora mucho más la práctica de la metaficción. El título de la obra procede de Sánchez Mazas, que había dicho a sus compañeros que escribiría la historia de Los soldados de Salamina (73), cuya contraseña secreta sería: "Los amigos del bosque" (124); su libro debía ser un "relato real", como lo es en parte el de Javier Cercas. Sánchez Mazas, el dirigente de Falange más antiguo de España, soñaba "con implantar el temible régimen de poetas y condotieros renacentistas", pero se estableció un "simple gobierno de pícaros, patanes y meapilas" (134-5). Publicado en 2001, Soldados de Salamina se mereció el Premio Llibreter de Narrativa 2001 y varios más. Lleno de vida y de tremenda realidad, marcó un hito en la novelística de la Guerra Civil por su toma de conciencia ante una realidad histórica tan capital y logró imprimir un impulso a la novelística y la cinematografía de la lucha cainita que dura hasta hoy. ${ }^{13}$

Como complemento de lo que hemos visto hasta ahora acerca de la técnica de Cercas, mencionemos la novela primeriza del periodista Carlos Fonseca, Tiempo de memoria (2009). ${ }^{14}$ En este texto un profesor de Historia Contemporánea en la Universidad Complutense de Madrid encuentra por casualidad en los archivos militares una carta de un abogado a los padres de un fusilado en 1937, José Rico, y decide estudiar el caso. Cuenta poco a poco cómo logra desentrañar el secreto, la verdad, la "memoria" a base de muchos esfuerzos, pues parecía que no existiera tal personaje: "El cabo Rico era el protagonista de un suceso que nunca ocurrió, de algo que no llegó a ser. Al fin una víctima más de la barbarie de la guerra. Un perfecto desconocido salvo para su familia" (280).

El trabajo de investigación le parece al narrador "Una tarea que les correspondía a los historiadores españoles y no a los hispanistas ingleses y americanos que les habían arrebatado la iniciativa en el estudio del Franquismo y de algunos de los episodios más relevantes de la Guerra" (23). Carlos Fonseca demuestra así cierto recelo hacia los extranjeros y su intención es tomar las riendas de lo propiamente español. El diario de José Rico encontrado por el profesor cubre momentos importantes, desde el 26 de julio de 1936 hasta el 16 de abril de 1937, víspera de su fusilamiento, y viene a completar los datos del periodista. Constituye una voz capital en esta triste tragedia así como la del hermano más joven que quiso quedar anónimo "para pagar la deuda de la memoria que tenemos con quienes perdieron la guerra" (283). ${ }^{15}$

Encontramos la misma búsqueda de un personaje, a la cual se añade la de un libro, en La sombra del viento Carlos Ruiz Zafón. Tuvo una gran 
resonancia en España y está traducida a cuarenta idiomas; viene a probar que la metaficción puede agradar no solo al lector refinado y escogido sino también al gran público. La sombra del viento se presenta como la serie de investigaciones que efectúa un adolescente. Bildungsroman muy denso, construido como una novela "gótica" y un thriller policiaco, lleno de misterio, con múltiples personajes y narradores en primera persona del verbo, este Premio Planeta 2001 se lee bien gracias a su estilo personal, a menudo irónico y metafórico. El protagonista desenreda el hilo de Ariadna y descubre sombrías historias familiares, amores lícitos e ilícitos, celos recurrentes, odios que se resuelven solo con la muerte. La complejidad del relato es mucho mayor que en Soldados de Salamina y otras novelas mencionadas hasta aquí. Julián, el autor de "La sombra del viento", es decir, de la novela dentro de la novela, y Fumero, el policía, fueron compañeros de colegio. Fumero estaba enamorado de Penélope, que prefirió a Julián; por ello Fumero persiguió a Julián antes, durante y después de la Guerra Civil. El encarnizamiento de Fumero con su amigo de la adolescencia es otro ejemplo de lucha fratricida: "Como todas las guerras, personales o a gran escala, aquél era un juego de marionetas" (486).

Jordi Soler, hispanomexicano, pertenece a la segunda generación de los exiliados y ha publicado dos novelas referentes a la Guerra Civil: Los rojos de ultramar (2004) y La fiesta del oso (2009). Esta última llama la atención por la fuerza que se desprende de ella, pero su lectura pide mucha atención. Narrada por un nieto de la Guerra Civil que decide emprender la búsqueda de un familiar pianista, que casi todos creen fallecido en 1939, o por lo menos con una vida gloriosa en algún país lejano, esta novela es fascinante desde el principio. Poco a poco el sobrino nieto del soldado republicano supuestamente muerto en la retirada se va enterando de detalles nuevos y continúa sus pesquisas: Oriol salió de Cataluña en febrero de 1939, había luchado en el Ejército republicano y tenía una herida grave en una pierna, trató de cruzar el Pirineo con dos conocidos recientes y allí murió, según se cree. Pero en realidad, una vez en Francia, Oriol había cambiado totalmente, convirtiéndose en un depredador de familias y de niñas indefensas, en un traidor: "Terminó desembocando en un proceso irreversible de envilecimiento, de animalidad, de descenso al pantanal de la especie" (57), "era un malvado, un desalmado, pero también daba lástima" (81), concede el narrador, pero a medida que sabe más siente pena y vergüenza de que Oriol sea un ogro, "un hombre despreciable que lleva mi apellido" (119), y se queda horrorizado al constatar la animalización a la cual ha llegado su tío abuelo en La fiesta del oso. "Work in progress" como escribe el narrador, "ahora que voy poniendo todo esto por escrito" (81). 
En este libro cada detalle es importante, no sobra ni una frase; por otra parte, recuerda los esperpentos de Valle-Inclán por sus hipérboles y sus notas de humor a menudo chirriante. La primera parte, con la repetición de "Se sabe" y la descripción de la lucha contra los elementos en la huida hacia la libertad, es espléndida; luego se confirma que lo que se sabía no terminaba como se había concluido. El autor se muestra de acuerdo con la temática de la memoria histórica, afirmando que la "puta guerra y sus secuelas ... son un lastre en la medida en que se ignoran, y constituyen un vehículo importante para proyectar el futuro si se desvelan a fondo todos sus detalles" (32).

El gallego Ramón Pernas había publicado una narración sobre la lucha cainita, Paso a dos en 1999, y en Del viento y la memoria (2006) lleva a la novela a unos falangistas, "vinculados por un ideal, por una ideología que creyó modificar la historia" (119), que hicieron estragos unos días antes del estallido del conflicto, el 18 de julio de 1936: cinco de ellos llegaron a una pequeña ciudad gallega e incendiaron la biblioteca. ${ }^{16}$ Se declaró la guerra, murieron varias personas, y se dió la orden de quemar los libros que quedaron; solo se salvaron algunos. El narrador nació en 1941, y pronto le animó su padre a escribir la historia del suceso. Cuenta la vida de cada uno de los criminales. Uno de ellos desapareció dos semanas después del incendio, y los otros vivieron largos años con remordimientos por su actuación y recibieron de forma extraña un tomo rescatado del fuego, tal como le fue enviado al narrador la Divina Comedia. Setenta años después de lo sucedido, se ha reconstruido la biblioteca gracias al dinero del hijo de uno de ellos y el narrador pronuncia el discurso de inauguración.

El libro es otra metaficción, y las reflexiones del narrador recalcan sus trabajos para llegar a su meta: "Mi mayor ambición consistió en contar esta historia que ahora mismo están leyendo, contarla y escribirla, escribirla y publicarla y hacerla llegar a un universo plural" (19). En otro lugar habla de él mismo como de Román Perlas (95) y su libro resulta polifónico, pues varios cuentan la misma historia en diferentes momentos y épocas:

La historia pasó de padres a hijos y no hay celebración familiar, bautizo o boda, reencuentro tras un viaje, ... en que no aflore a la conversación de sobremesa. Todos los asistentes al ágape contarán la versión y ninguno lo hará tal y como se la contaron, también navega por la cabeza de las personas que la conocieron, de las gentes que la oyeron contar, y ha ido creciendo y multiplicándose al ser referida. (39)

De la misma manera, Andrés Sorel, Secretario General de la Asociación Colegial de Escritores de España, acude a la metaficción en sus dos novelas, 
La noche en que fui traicionada (2002) y El falangista vencido y desarmado (2006). La trama de las dos novelas es muy parecida excepto por el final. El segundo libro termina con un largo diálogo que tuvo el personaje principal con Dionisio Ridruejo y la desesperación de este hombre, que fue un falangista convencido: "Vencido, cautivo y desarmado el pensamiento, la memoria del falangista también ha concluido. Hasta que, y de esto no podemos escribir, ni siquiera medir el imaginario tiempo que resta para ello, se produzca el apagón definitivo, la solución final de la historia. ¿Se publicaron (se publicarán)i ?i ? novelas ese día?" (302; énfasis en el original). Varias citas más manifiestan una profunda reflexión sobre la escritura: "Quiero, mientras reconstruyo las páginas de la novela escrita por mi amigo, ver yo mismo esta historia, intentar seguir con mis pasos" (39); "Novela y realidad. Ficción y vida. Simulación y compromiso. Lenguaje artístico y lenguaje histórico" (282).

Libro polifónico y multiperspectivista con sus fragmentos de cartas, conferencias, relatos del abuelo de Silvia, diálogo con Ridruejo, y, sobre todo, libro político: publicado en el año 2006, choca por su virulencia contra todo lo que representó la España nacional, pues por lo general a esas alturas las pasiones se habían apaciguado. El tono es a menudo violento y los calificativos denigrantes contra todo lo que representa el "enemigo": los jefes falangistas (José Antonio: "impotente, estúpido"), todos los generales franquistas y sobre todo Franco "sapo iscariote" (40), "En la Legión le pusieron el apodo de 'Franco el de las tres m: sin miedo, sin mujer, sin misa"' (42); "taimado y astuto enfermo mental ... eunuco" (44), ha envenenado "los sueños y las realidades de millones de personas" (115). Libro "no correcto, ni política ni literariamente", reza la contraportada.

El único libro en lengua catalana que reseñaré es el de Carme Riera, La meitat de l'ànima (La mitad del alma), uno de los mejores sobre la presencia de personajes niños, tipo muy frecuente en la novelística actual, como señalé anteriormente. Este Premio Sant Jordi 2003, de título significativo de la memoria escamoteada, de la niñez turbada por los recuerdos de la guerra y la posguerra, de la vida truncada entre un hombre partidario de los vencedores y una mujer, hija de vencidos que no ha podido olvidar ni perdonar, cautiva la atención del lector. La narradora, una escritora de cierta fama, trata de "rehacer los pasos" (11) de una mujer, Cecilia Balaguer, también llamada Celia Ballester, fallecida en 1960, pues el 23 de abril del 2001 un hombre le entregó una carpeta con once cartas que cambiaron su vida: Cecilia Balaguer era su madre. Descubre entonces a una mujer desconocida por ella, sospecha que ayudaba a los Republicanos en Francia, que se suicidó por despecho amoroso hacia un escritor famoso y 
que ella es hija del adulterio. Busca afanosamente en el país vecino y en Mallorca rastros de Cecilia, sin lograr encontrar la verdad, y pide tanto al hombre que le entregó las cartas como al público lector que le den datos necesarios para reconstituir la verdad sobre su madre y ella misma.

Se trata de una obra apasionada y apasionante, muy compleja, pues la narradora escribe "para ahuyentar los fantasmas y clarificar la realidad", para "tratar de entenderme y entender a los demás" o para "escapar de tanta miseria" (15), y para ello obra como un detective y va hurgando en el pasado durante dos años, al tiempo que trata de interpretarlo. El relato va zigzagueando según las investigaciones, y las desesperanzas siguen a los pocos momentos de ilusión. La autora juega constantemente entre la realidad y la ficción: al dirigirse por medio de su escritura al hombre desconocido que le dejó la carpeta, a todos los que la puedan ayudar para esclarecer su vida - "Me dirijo ... a todas las personas ..." (18); "Si Cecilia Balaguer fuera sólo la protagonista de una novela y no mi madre ..." (207); "Si Cecilia fuera sólo un personaje de mi invención ..." (208); "Si Cecilia Balaguer en vez de ser mi madre fuera la protagonista de una novela ..." (215) - recalca la narradora una y otra vez. Así involucra al lector en su pesquisa, le hace cómplice de su dolor y congoja, aportando algo muy original, nuevo, en la narrativa metaficcional.

Jorge Semprún es el autor que más complejidad le da a su texto Veinte años y un día (2003). Es una espléndida novela, en la cual las intrigas se multiplican así como los personajes y las pasiones prohibidas. En Quismondo, en la provincia de Toledo, el 18 de julio de 1936, unos campesinos han asesinado al más joven de la familia del rico dueño de una finca, que acababa de casarse. Desde entonces, el mayor de la familia exige que cada 18 de julio los campesinos representen este crimen en señal de expiación. Entonces, el 17 de julio de 1956 llega a Quismondo un historiador y profesor norteamericano de San Diego, Michael Leidson, hijo de una sefardita y de un judío de Riga, especialista de la Guerra Civil y de Hemingway. Varias personas acuden y varios residentes de la finca están presentes. Esperan un "plante" de parte de los braceros, pues estos no quieren volver a representar el asesinato y se teme una revuelta. Por la noche, Mercedes, la viuda del asesinado, manda llamar a Leidson a su habitación, le cuenta los pormenores de su viaje de novios, y el "gringo guapo" (72) sabe lo que se espera de él. Tiene lugar la "función" sin problemas, entierran en la misma cripta, en signo de reconciliación, al heredero Avendaño y a Chema, "el Refilón", nacido en la finca pero que fue luego guerrillero y murió en la cárcel de Burgos. En 1985 Leidson encuentra a Federico Sánchez, uno de los nombres de Semprún en la 
clandestinidad, y hablan de la posibilidad de que este escriba una novela sobre la familia Avendaño y su rito de expiación tan extraño y macabro.

Desde el principio, el narrador deja flotar un clima de sospecha, de incertidumbre que durará hasta el final: el profesor norteamericano y un comisario investigan. El primero sobre el ritual, y el segundo, sobre un personaje célebre de la clandestinidad, Federico Sánchez, próximo a Lorenzo, el hijo del difunto José María. Y si bien dicho ritual constituye el centro de la trama, alrededor de ello gira un sinfín de intrigas, y hábilmente "el Narrador - ¿o tan sólo es escriba, escribidor o escribano?" (82) - va interrumpiendo constantemente el hilo de la narración e introduciendo nuevos hechos, personajes, elementos - "cuenta en desorden, por asociaciones de ideas, de imágenes o de momentos, hacia atrás, hacia delante" (244) -; las analepsis se multiplican y surgen algunas prolepsis. El viaje de novios de la bella Mercedes con José María, el "derecho de pernada" que ejerce José Manuel, las relaciones incestuosas de los gemelos Lorenzo e Isabel, el erotismo desbordante de la familia, todo ello está descrito con detalle y contrasta con el ambiente generalmente conocido de la época. La cultura, la filosofía, la pintura, la literatura, la poesía, el teatro y la novela, con Lorca, Alberti, Hernández, el Quijote, todo ello aparece en múltples páginas, así como los fragmentos en francés, en inglés, en alemán, los juegos de palabras...

La política, sobre todo antifranquista, con varios nombres muy conocidos de los jóvenes clandestinos, forma uno de principales trasfondos del texto con la omnipresencia de la Guerra Civil, cuya continuación se celebra en la Maestranza: 'Nuestra guerra' - murmuró [Hemingway]. Todos decís lo mismo. Como si fuese lo único, lo más importante al menos que podéis compartir. El pan vuestro de cada día. La muerte, eso es lo que os une, la antigua muerte de la Guerra Civil", a lo cual contesta Larrea otro seudónimo de Federico Sánchez -: “¿Nuestra guerra o nuestra Juventud?" (232). A lo largo del texto (escrito en español como Autobiografía de Federico Sánchez y Federico Sánchez se despide de ustedes, y contrariamente al resto de la inmensa obra de Semprún escrita en francés) el lector acaba por estar seguro de que el narrador es Federico Sánchez, que es también personaje y cercano al autor. Dicho narrador omnisciente juega frecuentemente el papel de burlón: "A estas alturas, en efecto, no es posible, y con los elementos que tenemos a mano, suplir con algún artilugio narrativo aquella falta de atención de Mercedes: tenemos que someternos al azaroso pero imperativo contexto de la situación" (63).

Metanovela - "la novela de aquella antigua muerte de 1936 surgió en su mente, de pronto, de cuerpo entero" (232) -, se podría parecer a Absalón, Absalón de Faulkner, confiesa Leidson en 1985 a Federico Sánchez 
(242). Novela de estructura circular y multiperpectivista: el mismo relato del asesinato ha sido contado por tres personajes antes de que Federico Sánchez se decidiera a escribirlo. El autor y el narrador se funden a menudo en uno solo, la confusión de la instancia enunciativa es notoria en el juego constante entre el narrador anónimo y Federico Sánchez; Semprún se hace personaje y se lee hacia el final del texto:

Me es difícil, a pesar de que me empeñe, escribir novelas que sean novelas de verdad: por qué a cada paso, a cada página, me topo con la realidad de mi propia vida, de mi experiencia personal, de mi memoria: ¿para qué inventar cuando has tenido una vida tan novelesca, en la cual hay materia narrativa infinita? Ahora bien, la novela auténtica es un acto de creación, un universo falso que ilumina, sostiene y acaso modifica la realidad. Habría que poder decir como Boris Vian: en este libro todo es verdad porque me lo he inventado todo. Yo también quisiera inventármelo todo. (250-251)

La metaficción moderna se discute desde finales de los años setenta del siglo pasado. Tardó un poco en llegar a España y parece que los trágicos acontecimientos de los años treinta y la Ley de la Memoria Histórica han dado una oportunidad a unos cuantos novelistas españoles para lanzarse a una aventura literaria diferente de la tradicional, a utilizar un tema con una antigüedad de ochenta años y presentarlo de forma nueva, con técnicas más audaces.

He tratado de hacer ver con mi trabajo una progresión en el recurso de los novelistas a una estrategia hasta entonces poco usada, desde el sencillo empleo del texto de un supuesto autor, pasando por la reelaboración de algún texto ajeno, la implicación directa del autor en su propio texto, la cocreación, la llamada al lector para que participe y la forzosa actitud activa del lector para desenmarañar la trama y su autor. Casi todos los personajes principales de las metanovelas que he comentado son lo que se podría llamar "intelectuales", es decir, periodistas, profesores, investigadores, novelistas, y en su mayoría partidarios de la República. Todos tienen carrera o por lo menos estudios universitarios (menos el adolescente de Ruiz Zafón) y buen nivel cultural, están al tanto de la literatura actual, conocen el "mundillo" literario, y su intención es atraer al lector más sobre el "cómo" se hace el libro, que sobre la acción misma. De allí que algunas de las obras parezcan de lectura un tanto difícil o que pidan más atención al lector que una novela de tipo realista.

Si examinamos el inmenso corpus de la novelística de la Guerra Civil, compuesto de unos mil seiscientos textos, más de la mitad se acerca a la vida personal del autor. Además, miles de autobiografías y de memorias se 
han publicado sobre la guerra. Entonces, para el novelista que quiere utilizar estos acontecimientos como tela de fondo, hay que reconocer que se presta bien la narrativa ficticia: puede recurrir a su propia historia, transformarla, ajustarla a las normas de la metaficción, o retomar un texto ya supuestamente publicado, señalando su uso, corrigiendo, suprimiendo, mejorándolo.

Ruiz Marcos, en La memoria y el silencio, reivindica la primacía de la novela sobre la historia para llegar a la verdad de los hechos, mientras que Andrés Trapiello en Días y noches y Nativel Preciado en Camino de hierro apoyan la preeminencia de la historia sobre la novela. Preciado se pregunta si vale la pena escribir "otro" libro sobre la guerra, cuando ya hay tantos, y confiesa que no puede ser aséptica, pues lo vivido por su abuelo le pesa demasiado. Isaac Rosa, por su parte, en su novela de título escandaloso, ¡Otra maldita novela sobre la Guerra Civil!, viene a subrayar la abundancia de libros escritos sobre la Revolución del 36. Como Preciado, Rosa señala la relevancia que ha cobrado el tema recientemente, critica de manera violenta varios textos pero sin nombrarlos, reniega hasta del suyo, comenta la dificultad de publicar en la España de su momento y despotrica contra sus contemporáneos. Así lo hace también Mollà Ayuso en Perdidos en la memoria.

Juan Manuel de Prada, Javier Cercas y Ramón Pernas nos cuentan parte de su vida personal, a saber, cómo escriben, los problemas que encuentran, los pasos necesarios para encontrar la información, los escollos que tienen que sobrellevar para llegar a su objetivo. Escribir es su función principal, quieren contar historias, publicarlas y así darse a conocer; buscan la fama, cada uno a su manera. Todos ansían ser célebres. Carme Riera, por su parte, finge narrar su propia adolescencia y vida adulta en La mitad del alma y funciona de la misma forma, si bien con mayor emoción y hasta congoja, pero no logra encontrar a su madre.

Semprún quizá sea el que más habla de sí mismo en Veinte años y un día, como lo ha hecho en gran parte de su numerosa obra. A veces lo hace objetiva, otras más íntimamente, pero en conjunto el lector tiene la impresión de que, a pesar de los sufrimientos que supusieron para él la Guerra Civil, el exilio, el internamiento en los campos de concentración, los peligros de su vida clandestina en la España franquista, y lo sórdido del motivo de la reunión en 1956 en una finca de La Mancha, él ha superado toda esa época y logra ser burlón, pareciendo incluso divertirse al escribir y al jugar con sus propias identidades. Carlos Ruiz Zafón en La sombra del viento recurre a un adolescente que va en busca no de un personaje o de acontecimientoso sino de un libro, "La sombra del viento", y de su autor. Inserta un libro en su libro, mezcla los subgéneros literarios, la novela de 
aprendizaje, la novela gótica y la metanovela, creando una obra que, con razón, tuvo y sigue teniendo mucha resonancia. ${ }^{17}$

La palabra "memoria" figura en muchos títulos de las novelas estudiadas: El Club de la Memoria (Díaz Pérez), Tiempo de memoria (Fonseca), Perdidos en la memoria (Mollà Ayuso), Del viento y la memoria (Pernas) y La memoria del agua (Viejo). Todos sus protagonistas vuelven hacia su propio pasado o al de otros personajes - abuelos, abuelas, tío - se sienten desasosegados, incómodos en su ser, quieren encontrar la razón de tal malestar, se preguntan cómo pudo ser que se enfrentaran así los españoles, hermano contra hermano. La mayor parte de ellos necesita comprender qué pasó para hallar la paz, pero todos condenan esa parte de la historia de su país; sin embargo, apenas se percibe un deseo de perdón, de reconciliación.

La sima de José María Merino es la obra que más directamente se refiere a lo que fue objeto de tanta polémica a finales de la primera década del siglo XXI: la recuperación de cadáveres del tiempo de la guerra o del Franquismo. Su personaje acude a su pueblo, donde se tiraron a una caverna a hombres después de matarlos, y él sospecha que fue su abuelo franquista el que mandó cometer tan vil crimen. De manera muy sutil, el autor juega con la palabra "sima", utilizándola desde el punto de vista real, la caverna, y desde el punto de vista metafórico, su propio estado de ánimo. Estalla una bomba, cubriendo por completo la sima, y ya no se puede averiguar a quién pertenecen los cuerpos ahora encerrados para siempre, pero el personaje se ha recuperado a sí mismo, hallando a su amor de juventud, su prima Puri.

Los autores comentados son (eran) de todas las edades, desde el mayor nacido en 1923 (Jorge Semprún, fallecido en 2011), hasta el más joven en 1974 (Isaac Rosa); el primero más sereno, el segundo más rabioso. Varios de ellos se han merecido premios literarios de prestigio: recordemos a Carlos Ruiz Zafón (Premio Planeta 2001, Prix des libraires du Québec 2003 y Premio al mejor libro extranjero en Francia 2004), Javier Cercas (varios premios en 20o1: el Premio Llibreter de Narrativa, el Premio Ciudad de Barcelona, el Premio Salambó y el Premio de Crítica de Chile), Carme Riera (Premio Sant Jordi 2003), Bernardo Atxaga (Premio de la Crítica 2004), Jorge Semprún (Premio José Manuel Lara 2004) y Nativel Preciado (Premio Primavera de Novela 2007). Si bien los premios no significan siempre calidad, por lo menos algo anuncian cierto valor literario y la lectura de casi todos los libros estudiados en las páginas anteriores tienen su interés, con su "inserción de lo ficticio en lo ficticio", como escribe José María Merino en Ficción continua. Así crean "una 
apariencia que tiene mucho que ver con el viejo mito, tan arraigado en lo español, en que vida y sueño acaban confundiéndose" (27).

\section{Université de Montréal}

\section{NOTAS}

1 Más 40.00o mil títulos se pueden registrar hasta ahora sobre el tema. Véase Bertrand de Muñoz (2012).

2 En este centro se encuentra la colección de "Novelas de la Guerra Civil" de Maryse Bertrand de Muñoz.

3 Esta obra de título atrevido y significativo de la gran cantidad de novelas sobre la Guerra Civil había sido precedido por El batallón de los perdedores, de Salvador Gutiérrez, en cuya portada se lee: "Una novela cafre, divertida y políticamente incorrecta sobre el exceso de libros de la guerra civil española y las miserias del mundillo literario".

4 Cabría señalar también la novela finalista del Premio Nadal 2008, El Club de la Memoria de Eva Díaz Pérez, que alude a dicho Club durante la República, el cual formaba parte de las célebres Misiones Pedagógicas.

5 El presente trabajo recoge y amplía la tercera parte de mi artículo "Las grandes tendencias de la novela de la Guerra Civil en el sigo XXI".

6 El de don Pedro, el primer americano de Obaba, propietario del Hotel Alaska (240-282), y las "Tres confesiones" (444-469).

7 Una técnica semejante encontramos en la reciente novela de Luis Llach: Las mujeres de la Principal.

8 Rodrigo, el hombre que ayudó a Paula, su amiga Francesca, por medio de mensajes informáticos, el abuelo y Lucas en sus cartas, la tía Olvido, la abuela.

$9 \quad$ En "Littérature et métalangage" Barthes define así la metaliteratura: "Cuando la literatura empieza a sentirse doble, a la vez objeto y mirada sobre este objeto, palabra y palabra de esta palabra, literatura objeto y metaliteratura ... conciencia artesanal de la fabricación literaria" (106-108; mi traducción).

1o Ver también la obra de Patricia Waugh, Metafiction. The Theory and Practice of Self-Consciousness.

11 Otros tres novelistas del período 2000-2010 han utilizado el mismo tipo de protagonista: Gustavo Martín Garzo en El valle de las gigantas (2000), Alfredo Conde en Memoria de soldado (2002) y Joaquín Leguina en El rescoldo (2004). Todos tienen protagonistas niños que van a buscar información acerca de estos ancianos, lo que es esencial para seguir viviendo en paz con ellos mismos, para reconciliarse con la vida y la sociedad.

12 En otra novela, El séptimo velo (2007), de Prada plantea el caso de un hombre 
que va en busca de su padre como Carmen Riera (véase más adelante) lo hace con un personaje que busca a su madre y Javier Cercas a un célebre falangista; todos refieren las etapas para alcanzar su meta. Hay que señalar también una reciente novela, XIV Premio Vargas Llosa, Hendaya (2011), de Marcos Eymar, en la cual el protagonista busca afanosamente a su padre pero sobre todo a sí mismo.

13 La película Soldados de Salamina, basada en la novela homónima de Javier Cercas, se estrenó en 2003.

14 Carlos Fonseca es autor del libro muy conocido Trece rosas rojas (2004), que inspiró varios textos narrativos y fílmicos.

15 Hay que mencionar también en la misma línea la novela menor de Teresa Viejo, La memoria del agua (2009).

16 Hay que señalar aquí otro metarrelato importante que refiere la quema de libros: Los libros arden mal (2006) de otro gallego, Manuel Rivas. Presenta un amplio fresco del siglo XX y en él la Guerra Civil y la vergonzosa acción de prender fuego a los libros, que da el título al libro, cobra gran relieve pues significa la aniquilación de la cultura por los opositores a la República.

17 Recurre también a un texto ajeno Bernardo Atxaga con El hijo del acordeonista y lo remodela, lo completa pero se aleja de su autobiografía.

OBRAS CITADAS

Alter, ro bert. Partial Magic: the Novel as a Self-Conscious Genre. Berkeley: U of California P, 1975.

A X XaGA, BeRnAR D o. El hijo del acordeonista. Madrid: Alfaguara, 2004.

BARTHES, ROLLAND. "Littérature et métalangage". Essais critiques. París: Seuil, 1964. 106-174.

BERTRAN D D MUÑoZ, MARYSE. Bibliografía de la Guerra Civil española. 1936-1939. Madrid: UNED, 2012.

—. Bibliografía general de la Guerra Civil Española, 1936-1939. Libro electrónico. Ebook. Madrid: UNED, 2005.

—. Bibliografía general de la Guerra Civil Española, 1936-1939. CD-Rom. Madrid: UNED, 2007.

—. "Las grandes tendencias de la novela de la Guerra Civil en el sigo XXI". La Guerra Civil española. Un dolor que no se calla. Eds. María José Giménez Micó y Sonia Thon. Número especial de la Revista Canadiense de Estudios Hispánicos 36.1 (2011): 207-227.

CE R Cas, JAvier. Soldados de Salamina. Barcelona: Tusquets, 2001.

Ce RVAntes, Mi Gu El DE. Don Quijote de La Mancha. Madrid: Instituto Cervantes, 1998.

CHAMPEAU, GENEVIÈVE. “L'autoreprésentation dans le récit de la fiction”. Le roman 
espagnol actuel. Pratique d'écriture, 1975-200o. Coord. Anne Bussière-Perrin.

Tomo 2. Montpellier: Centre d'études et de recherches sociocritiques, 2001. 6598.

CONDE, ALFRED o. Memoria de soldado. Barcelona: Edhasa, 2002.

CROS, EDMOND. "Sujet culturel et postmodernité: remarques sur une

déshistoricisation". Postmodernité et écriture narrative dans l'Espagne

contemporaine. Actes du colloque international CERHIUS, Grenoble, 16-18 mars

1995. Ed. Georges Tyras. Grenoble: Université Stendhal, 1996. 15-22.

DA L e n B A C , L UCien. Le récit spéculaire. Essai sur la mise en abyme. París: Seuil:

1977.

Dí A Z PÉre Z, eva. El Club de la Memoria. Barcelona: Destino, 2008.

D OTRAS, ANA. La novela española de metaficción. Madrid: Júcar, 1994.

EYMAR, MAR cos. Hendaya. Madrid: Siruela, 2013.

fonseca, CARlos. Tiempo de memoria. Madrid: Temas de Hoy, 2009.

-. Trece rosas rojas. Madrid: Temas de Hoy, 2004.

GARZo, GUSTAVo MARTín. El valle de las gigantas. Barcelona: Destino, 2000.

GRANDES, ALMUDENA. El corazón helado. Barcelona: Tusquets, 2007.

GutiérRez solís, SA LVA D or. El Batallón de los Perdedores. Córdoba: Berenice-

Malaleche, 2006.

hut Che on, Linda. Narcissistic Narrative. The Metafictional Paradox. Waterloo:

Wilfrid Laurier UP, 1980.

Jако в о о, во м а . "Closing statements: Linguistics and Poetics". Style in

Language. Ed. T.A. Sebeok. New York: Wiley, 1960. 350-77.

LEG UINA, Jo A Quín. El rescoldo. Madrid: Santillana, 2004.

L LA CH, Luis. Las mujeres de la Principal. Barcelona: Seix Barral, 2014.

MER In O, JoSÉ MARÍA. El heredero. Madrid: Santillana, 2004.

—. La sima. Barcelona: Seix Barral, 2009.

mo llà a y us o, luis. Perdidos en la memoria. Chiclana, Marzo de 1939: La tragedia

del Castillo de Olite. Cádiz: JM Ediciones, 2010.

NA VAJ AS, G ONZA L o. "La novela española de la pos-nación". Insula 688 (2004): 13-15.

—. Más allá de la posmodernidad. Estética de la nueva novela y cine españoles.

Barcelona: EUB, 1996.

- . La narrativa española en la era global. Imagen, comunicación, ficción. Barcelona:

EUB, 2002.

—. Teoría y práctica de la novela española posmoderna. Barcelona: Edicions del

Mall, 1987.

PERnas, ramón. Paso a dos. Sevilla: Algaida, 1999.

-. Del viento y la memoria. Madrid: Espasa, 2006.

PRADA, JUA M M n E L D. Las esquinas del aire. En busca de Ana María Martínez

Sagi. Barcelona: Planeta, 2000.

—. El séptimo velo. Barcelona: Seix Barral, 2008. 
preciado, nativel. Camino de hierro. Madrid: Espasa, 2007.

RIERA, CARMEN. La mitad del alma. Madrid: Alfaguara, 2005.

RIVAS, MANUEL. Los libros arden mal. Madrid: Alfaguara, 2006.

RosA, IS A AC. ¡Otra maldita novela sobre la Guerra Civil! Lectura crítica de La

Malamemoria. Barcelona: Seix Barral, 2007.

RUIZ MARCOS, JoSÉ MANUEL. La memoria y el silencio. Oviedo: Laria, 2008.

RUIZ ZA Fón, CARlos. La sombra del viento. Barcelona: Planeta, 2001.

-. L'ombre du vent. Paris: Grasset, 2004.

SE M P R ú , J O R G. Autobiografía de Federico Sánchez. Barcelona: Planeta, 1977.

—. Federico Sánchez se despide de ustedes. Barcelona: Tusquets, 1993.

—. Veinte años y un día. Barcelona: Tusquets, 2003.

-. Vingt ans et un jour. Paris: Gallimard, 2004.

sobejano, gon Zalo. Novela española contemporánea, 1940-1995. Madrid:

Marenostrum, 2003.

Soldados de Salamina. Dir. David Trueba. Prod. Lola Films, 2003

SO LER, J ORD I. Los rojos de ultramar. Madrid: Alfaguara, 2004.

—. La fiesta del oso. Barcelona: Mondadori, 2009.

SOREL, ANDRÉs. La noche en que fui traicionada. Barcelona: Planeta, 2002.

-. El falangista vencido y desarmado. Sevilla: RD Editores, 2006.

SPIR E, R в в R T. Beyond the Metafictional Mode. Directions in the Modern Spanish

Novel. Lexington: UP of Kentucky, 1984.

TRAPIEllo, An DRÉs. Días y noches. Madrid: Espasa, 2000.

-. Les cahiers de Justo García. París: Buchet-Chastel, 2004.

viejo, teresa. La memoria del agua. Madrid: Martínez Roca, 2009.

WA U G H, PA T R I CIA. Metafiction. The Theory and Practice of Self-Conscious Fiction.

Londres: Methuen, 1984. 